\title{
Diversity of Social Wasps on Semideciduous Seasonal Forest Fragments with Different Surrounding Matrix in Brazil
}

\author{
Getulio Minoru Tanaka Junior ${ }^{1,2}$ and Fernando Barbosa Noll ${ }^{1}$ \\ ${ }^{1}$ Laboratório de Vespas Sociais, Departamento de Zoologia e Botânica, IBILCE-UNESP, Rua Cristóvão Colombo, \\ 2265 CEP 15054-000 São José do Rio Preto-SP, Brazil \\ ${ }^{2}$ Departamento de Biologia, FFCLRP-USP, Avenida Bandeirantes, 3900 CEP 14040-901 Ribeirão Preto-SP, Brazil
}

Correspondence should be addressed to Getulio Minoru Tanaka Junior, gtanaka@gmail.com

Received 17 December 2010; Accepted 15 February 2011

Academic Editor: Abraham Hefetz

Copyright (C) 2011 G. M. Tanaka Junior and F. B. Noll. This is an open access article distributed under the Creative Commons Attribution License, which permits unrestricted use, distribution, and reproduction in any medium, provided the original work is properly cited.

\begin{abstract}
We surveyed social wasps (Polistinae) present in forest fragments of northwest of São Paulo state with different surroundings composed of a matrix of citrus crops and sugarcane in the expectation that the former matrix would be more diverse than the latter. We collected specimens actively using attractive liquids. We obtained 20 species in Magda, 13 in Bebedouro, 13 in Matão, and 19 in Barretos. The most common genus was Agelaia in all of the areas. The greatest Shannon-Wiener index of diversity was obtained in Magda $\left(\mathrm{H}^{\prime}=2.12\right)$. Species such as Brachygastra moebiana, Metapolybia docilis, Mischocyttarus ignotus, M. paulistanus and $M$. consimilis had not been recorded on recent surveys in the state. Furthermore M. consimilis is a new record for the state. We concluded that, with our data, a relation between the occurrence of social wasps and the surrounding matrix was not detected.
\end{abstract}

\section{Introduction}

Forest fragments may be treated as islands, and the surrounding area, the matrix, is treated as an ocean. The matrix area is considered to be ecologically uniform, exerting little influence on populations inside the fragments $[1,2]$. More recently, some studies have demonstrated that the surrounding matrix can exert neutral, positive, or negative influences on the populations [3-5].

The replacement of natural areas by monocultures and pastures is one of the main causes of reduction of local and global diversity [6]. Besides habitat fragmentation, the use of pesticides and insecticides reduces the diversity of pollinators [7]. However, Durigan et al. [8] state that some crops have less impact on the natural vegetation than cattle. The majority of crops depend on or benefit from, the action of pollinators [9]. Pimentel et al. [10] show a great richness of arthropod species on many crops. Survey works are important because the survey of species in an area is the first step to its conservation and rational use. Without the knowledge of what species are present in an area, it is very difficult to take action aimed at conservation [11]. Pimentel et al. [10] assert that, as important as it is to conserve the biodiversity of national parks, it is important to conserve biological diversity in agricultural ecosystems, which, together with human settlements, cover approximately $95 \%$ of terrestrial environment [12].

Two of the most important monocultures in São Paulo state are sugarcane (Saccharum spp) and citrus (Citrus spp). Sugarcane is the main crop of São Paulo state with about 5.5 million hectares in 2007/2008 [13]. Regular use of burning facilitates manual harvest and repels venomous animals [14], but causes serious damage to the ecosystem [15] while the use of fertilizers may pollute watercourses and cause salinization of the soil [16]. Organic fertilization systems that can shelter a great biodiversity have been recommended [17]. Brazil is the world's greatest producer of oranges with about 18.5 million tons, and São Paulo State contributes about 15 million tons [18], grown on about 750 thousand hectares in 2007/2008 [13]. During the bloom, oranges offer a great production of pollen and nectar that can attract pollinators [19]. It would be useful to know if a survey of insects at a high trophic level reflects the matrix nearby with respect to the sterility (or toxicity) of some crops, 
such as sugarcane, and the productivity of others, such as oranges.

There are few data comparing areas with these two surrounding matrices and their possible effects to the biota. Rinaldi et al. [20] found a surprisingly high richness of spiders on sugarcane plantations. Ott et al. [21] sampled spiders on herbaceous vegetation in two different citrus orchards, "traditional" and "ecological," and despite the differences in cultivation practices, they found a lower richness than Rinaldi et al. [20]. Ott et al. [21] also did a survey on citrus trees of the "ecological" orchard, and there they found a greater richness of spiders species than Rinaldi et al. [20].

Andena et al. [22] did a survey of bees on an area that was previously surveyed by Campos [23] and found a lower richness of species. There were some changes in the surrounding matrix due to the replacement of the natural vegetation by sugarcane crops and pasture. The most common pollinator of Citrus in Brazil is Apis mellifera, but Tetragonisca angustula and Trigona spinipes are also frequent floral visitors [24, 25]. Other Hymenoptera and some Coleoptera, Diptera, Lepidoptera and Neuroptera also are floral visitors of Citrus [25]. A study in Rio Grande do Sul state observed five orders of predatory insects (Coleoptera, Hymenoptera, Neuroptera, Thysanoptera and Hemiptera) in canopies of $C$. deliciosa under organic management [26].

Social wasps have little importance with respect to pollination, but they are frequent floral visitors. Some of them collect nectar for colony's energy supply [27]. These insects show great ability to forage and collect other materials they need such as water, carbohydrates, prey and pulp [28-30], and are being used to control some pests [31]. After Richards [32], many surveying works have been done in different areas in Brazil using various methodologies [11, 33-55]. Here we compare four fragments of semideciduous seasonal forest of northwest of São Paulo state with a surrounding matrix composed of crops of citrus or sugarcane. Moreover, we compare those results to other surveys done in the same region.

\section{Material and Methods}

2.1. Study Area. Northwest of São Paulo state is the most deforested area of the state and with the lowest concentration of conservation units [56]. The natural vegetation of the region is characterized as semideciduous seasonal forest and cerrado (or brazilian savanna).

The study was conducted on fragments from the municipalities of Magda $\left(20^{\circ} 30^{\prime} \mathrm{S} 50^{\circ} 13^{\prime} \mathrm{W}, 1656.20 \mathrm{ha}\right)$, Bebedouro $\left(20^{\circ} 53^{\prime} \mathrm{S} 48^{\circ} 32^{\prime} \mathrm{W}, 393.94 \mathrm{ha}\right)$, Matão $\left(21^{\circ} 37^{\prime} \mathrm{S} 48^{\circ} 32^{\prime}\right.$ W, $2189.58 \mathrm{ha}$ ) and Barretos (20 $\left.29^{\prime} \mathrm{S} 48^{\circ} 49^{\prime} \mathrm{W}, 597.33 \mathrm{ha}\right)$. The first two had sugarcane crops as the surrounding matrix and the last two had citrus crops as the surrounding matrix.

2.2. Methods. The methodology used was based on active collection using an attractive liquid [57]. This methodology uses a $200 \mathrm{~m}$ transect in the vegetation on which is sprayed a solution of sucrose $(1: 5$, commercial sugar: water) with $2 \mathrm{~cm}^{3}$ of salt for each liter of solution. Using a costal sprayer,

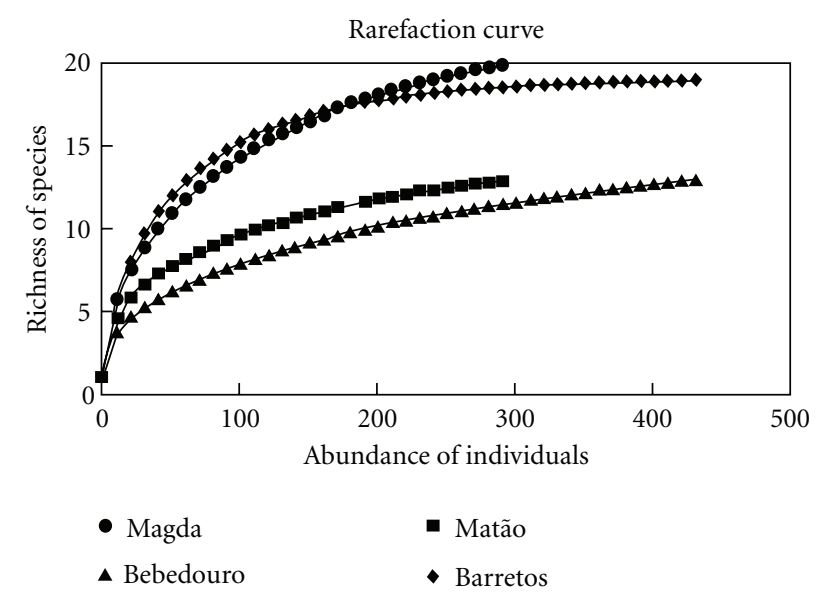

FIGURE 1: Rarefaction curve for the social wasps collected in the four studied areas.

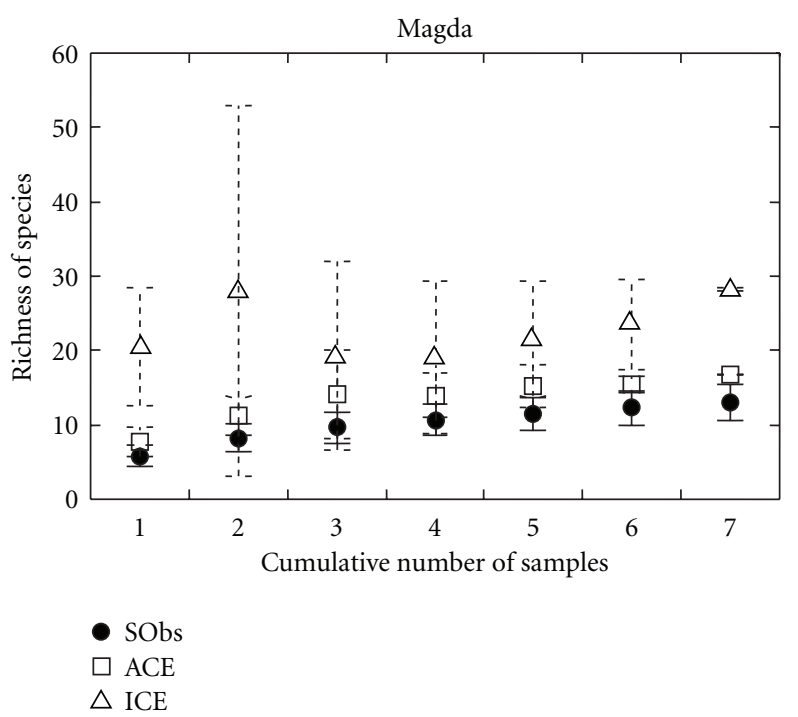

Figure 2: Richness of species observed and estimated using ACE (Abundance-based Coverage Estimator) and ICE (Incidence-based Coverage Estimator) indexes to the area of Magda.

about $500 \mathrm{~mL}$ of solution was sprayed on each point of collection, in an area of approximately $3 \mathrm{~m}^{2}$. Ten points were defined, $20 \mathrm{~m}$ distant from each other along the transect. The attracted wasps were captured with an entomological net, from 11:00 AM to 3:00 PM, during five minutes at each collecting point, with a spray interval of approximately $1: 30 \mathrm{~h}$. Collections were made in one transect in the interior of the forest fragment (at least $100 \mathrm{~m}$ of the edge), and one at the edge of the forest fragment, near the surrounding matrix.

Eight monthly collections were made in Magda (24 h of field work in the interior and $32 \mathrm{~h}$ at the edge), ten in Bebedouro ( $24 \mathrm{~h}$ of field work on the interior and $40 \mathrm{~h}$ on the edge), seven in Matão ( $24 \mathrm{~h}$ of field work in the interior and $28 \mathrm{~h}$ at the edge) and eight in Barretos ( $28 \mathrm{~h}$ of field work in the interior and $32 \mathrm{~h}$ at the edge) during the period of December 2007 to December 2009. The specimens collected 


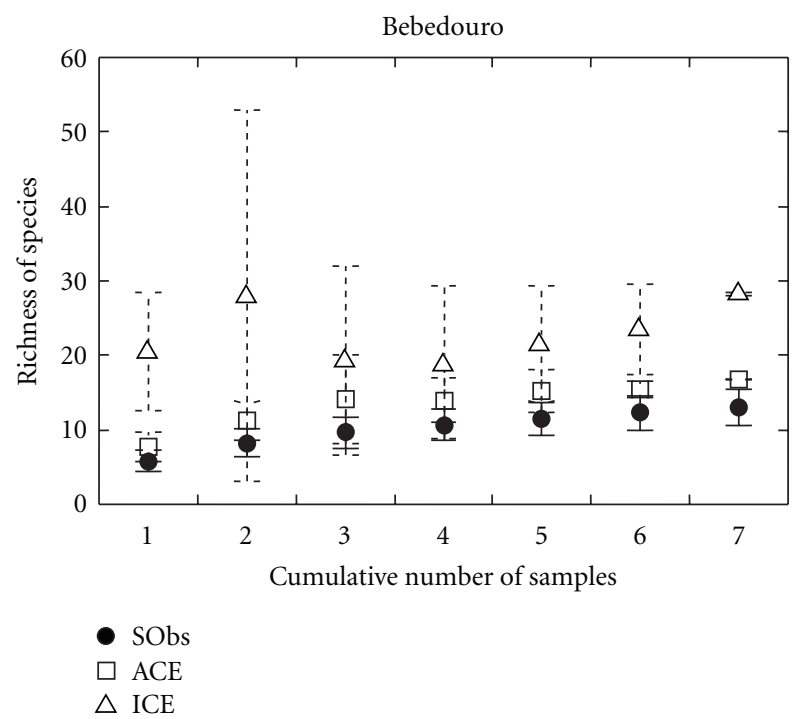

Figure 3: Richness of species observed and estimated using ACE (Abundance-based Coverage Estimator) and ICE (Incidence-based Coverage Estimator) indexes to the area of Bebedouro.

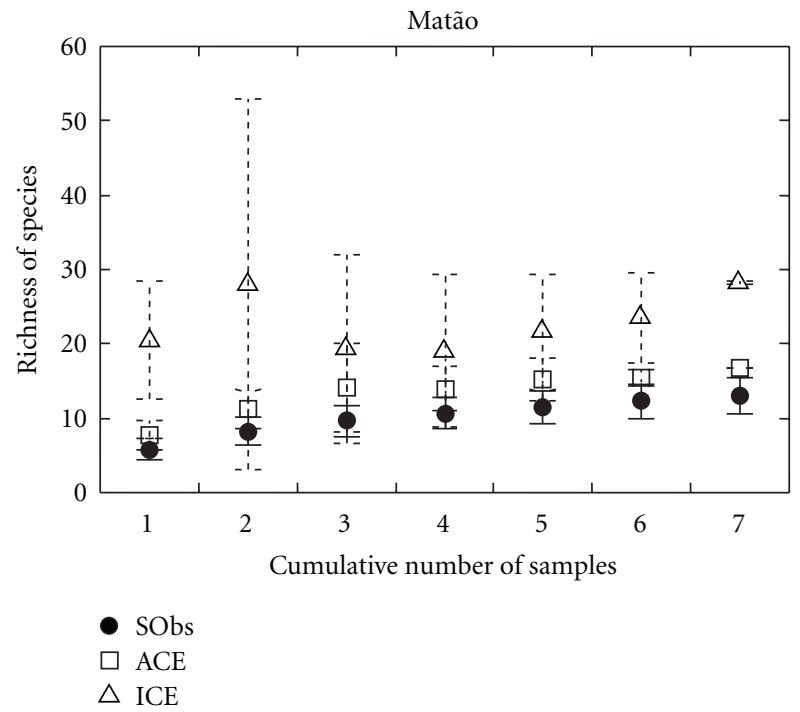

Figure 4: Richness of species observed and estimated using ACE (Abundance-based Coverage Estimator) and ICE (Incidence-based Coverage Estimator) indexes to the area of Matão.

were identified and deposited in the Hymenoptera Collection at the Department of Zoology and Botany, São Paulo state University, São Jose do Rio Preto, Sao Paulo, Brazil.

2.3. Statistical Analysis. Shannon-Wiener index of diversity, Berger-Parker index of dominance, Pielou index of evenness, and similarity analysis of Jaccard and Morisita-Horn were done using the software PAST, version 1.37 [58]. ACE (Abundance Coverage Estimator) and ICE (Incidence Coverage Estimator) indexes were used to estimate the richness using the software Estimates version 7 [59]. A rarefaction curve

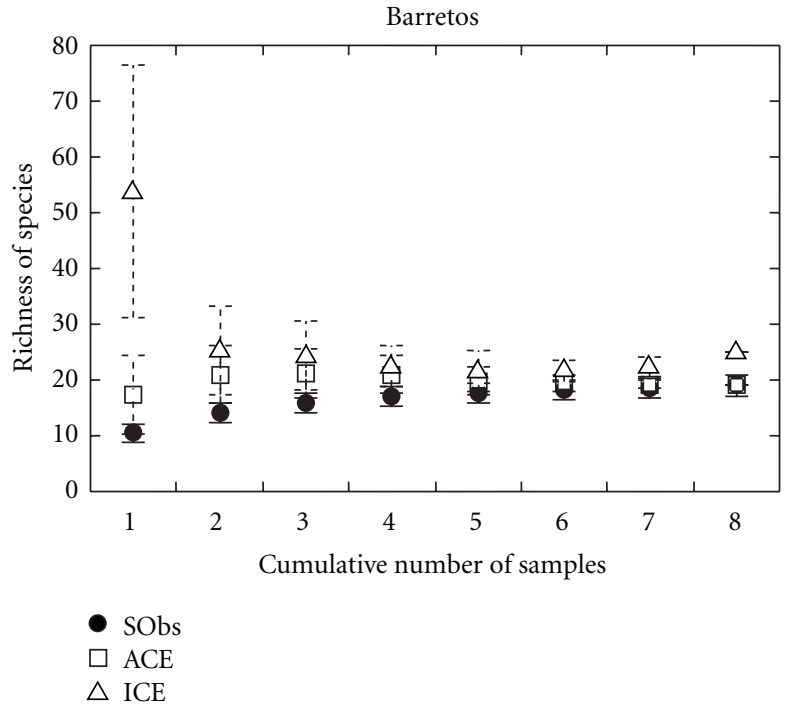

Figure 5: Richness of species observed and estimated using ACE (Abundance-based Coverage Estimator) and ICE (Incidence-based Coverage Estimator) indexes to the area of Barretos.

model of Hulbert was done on Biodiversity Professional Beta $[60]$.

\section{Results and Discussion}

Twenty-nine species of social wasps belonging to 10 genera were collected in the four areas of study totalling 1460 individuals (Table 1 ).

Matão was the well-preserved area of study, the largest one, and was surrounded by citrus crops. It was expected to be the richest, but it was the poorest in number of species along with Bebedouro, the poorly preserved site, and it was surrounded by sugarcane crops. Also, Barretos, with a small area and citrus crops on its surrounding, had almost many species as Magda, the second largest area and the fragment that showed the greatest richness of social wasps.

In terms of surrounding matrix, it was expected that the fragments located on sugarcane matrix should have lower diversity because of the effects of the fire on the local fauna and the lack of flowers that could attract some wasps (unlike citrus crops), but this was not verified in our work. That null difference between diversity in those surrounding matrices could be supposedly explained by the fast recovery of an area after a burning event (as observed by Araújo et al. [15]) or a possible more intensive use of insecticides on citrus crops [61].

Our collections include species that merit particular notice. We collected species that represent significant records: Brachygastra moebiana, Metapolybia docilis, Mischocyttarus ignotus, M. paulistanus, and M. consimilis had not been recorded by recent surveys in São Paulo State; furthermore M. consimilis is a new record to the state. Polybia jurinei was the most abundant species in Magda, Agelaia multipicta was most abundant in Matão, and A. pallipes was most abundant in Bebedouro and Barretos. The genus Agelaia has species 


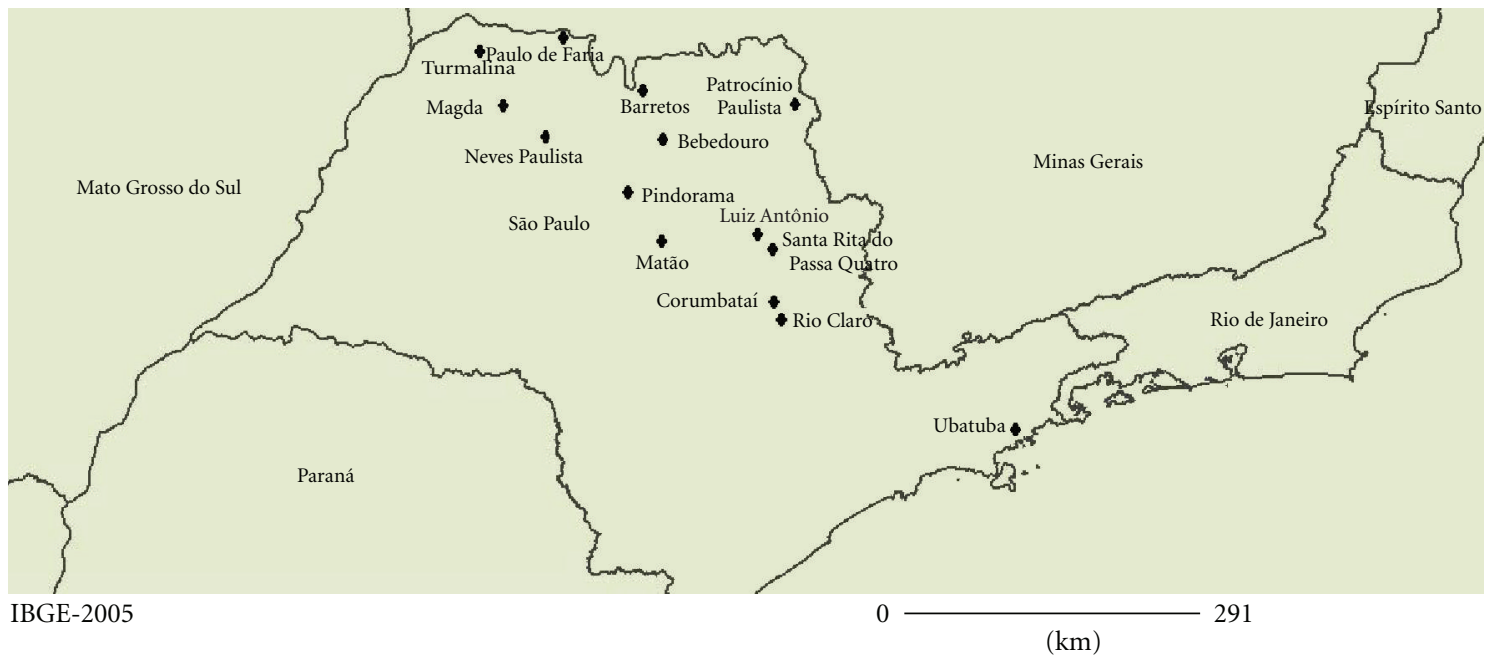

Figure 6: Map showing the localization of the areas of São Paulo state where surveys of social wasps were done.

TABLE 1: List of social wasps species collected on the four areas studied. E: edge; I: interior; T: total. Magda and Bebedouro: sugarcane crops. Matão and Barretos: citrus crops.

\begin{tabular}{|c|c|c|c|c|c|c|c|c|c|c|c|c|}
\hline \multirow{3}{*}{ Species } & \multicolumn{12}{|c|}{ Areas } \\
\hline & \multicolumn{3}{|c|}{ Magda } & \multicolumn{3}{|c|}{ Bebedouro } & \multicolumn{3}{|c|}{ Matão } & \multicolumn{3}{|c|}{ Barretos } \\
\hline & $\mathrm{E}$ & I & $\mathrm{T}$ & E & I & $\mathrm{T}$ & E & I & $\mathrm{T}$ & $\mathrm{E}$ & I & $\mathrm{T}$ \\
\hline Agelaia multipicta & 33 & 28 & 61 & - & - & - & 45 & 89 & 134 & - & - & - \\
\hline Agelaia pallipes & 30 & 29 & 59 & 100 & 161 & 261 & 1 & - & 1 & 101 & 94 & 195 \\
\hline Agelaia vicina & 20 & 25 & 45 & 21 & 44 & 65 & 40 & 18 & 58 & - & - & - \\
\hline Brachygastra moebiana & 4 & - & 4 & - & - & - & - & - & - & 21 & - & 21 \\
\hline Brachygastra augusti & - & - & - & 1 & - & 1 & 2 & - & 2 & 9 & - & 9 \\
\hline Brachygastra lecheguana & 1 & 1 & 2 & 4 & - & 4 & 4 & - & 4 & 11 & - & 11 \\
\hline Brachygastra mouleae & 1 & - & 1 & - & - & - & 1 & - & 1 & 3 & - & 3 \\
\hline Metapolybia docilis & 1 & - & 1 & - & - & - & - & - & - & 1 & - & 1 \\
\hline Mischocyttarus cerberus styx & 6 & 3 & 9 & - & - & - & - & - & - & - & - & 一 \\
\hline Mischocyttarus ignotus & 2 & - & 2 & - & - & - & - & - & - & - & - & - \\
\hline Mischocyttarus paulistanus & 2 & - & 2 & 1 & - & 1 & - & - & - & - & - & 一 \\
\hline Mischocyttarus rotundicollis & - & - & - & - & - & - & 2 & - & 2 & - & - & - \\
\hline Mischocyttarus consimilis & 1 & - & 1 & - & - & - & - & - & - & - & - & 一 \\
\hline Parachartergus smithii & 1 & - & 1 & - & - & - & - & - & - & 2 & 1 & 3 \\
\hline Polistes simillimus & 4 & 4 & 8 & 2 & - & 2 & - & - & - & 8 & 1 & 9 \\
\hline Polistes versicolor & 3 & 1 & 4 & - & - & - & 38 & 2 & 40 & 3 & 1 & 4 \\
\hline Polistes geminatus & - & 2 & 2 & - & - & - & - & - & - & - & - & 一 \\
\hline Polybia jurinei & 40 & 30 & 70 & - & 1 & 1 & 2 & 3 & 5 & 20 & 29 & 49 \\
\hline Polybia dimidiata & - & - & - & 35 & 21 & 56 & - & - & - & 3 & - & 3 \\
\hline Polybia fastidiosuscula & - & - & - & - & - & - & - & - & - & 6 & - & 6 \\
\hline Polybia occidentalis & 5 & 1 & 6 & 7 & - & 7 & 23 & - & 23 & 36 & 3 & 39 \\
\hline Polybia paulista & - & - & - & - & - & - & - & - & - & 22 & 9 & 31 \\
\hline Polybia ruficeps xanthops & - & - & - & - & - & - & - & - & - & - & 4 & 4 \\
\hline Polybia chrysothorax & - & - & - & - & - & - & 14 & 8 & 22 & - & - & 一 \\
\hline Polybia ignobilis & 14 & 3 & 17 & 20 & 6 & 26 & 1 & - & 1 & 15 & 8 & 23 \\
\hline Polybia sericea & 3 & - & 3 & 2 & - & 2 & - & - & - & 5 & - & 5 \\
\hline Protonectarina sylveirae & - & - & - & 4 & - & 4 & 4 & - & 4 & 7 & - & 7 \\
\hline Protopolybia exigua & - & - & - & 1 & - & 1 & - & - & - & - & - & 一 \\
\hline Synoeca surinama & 2 & 一 & 2 & 一 & 一 & 一 & 一 & 一 & 一 & 9 & - & 9 \\
\hline Total & 173 & 127 & 300 & 198 & 233 & 431 & 177 & 120 & 297 & 282 & 150 & 432 \\
\hline
\end{tabular}




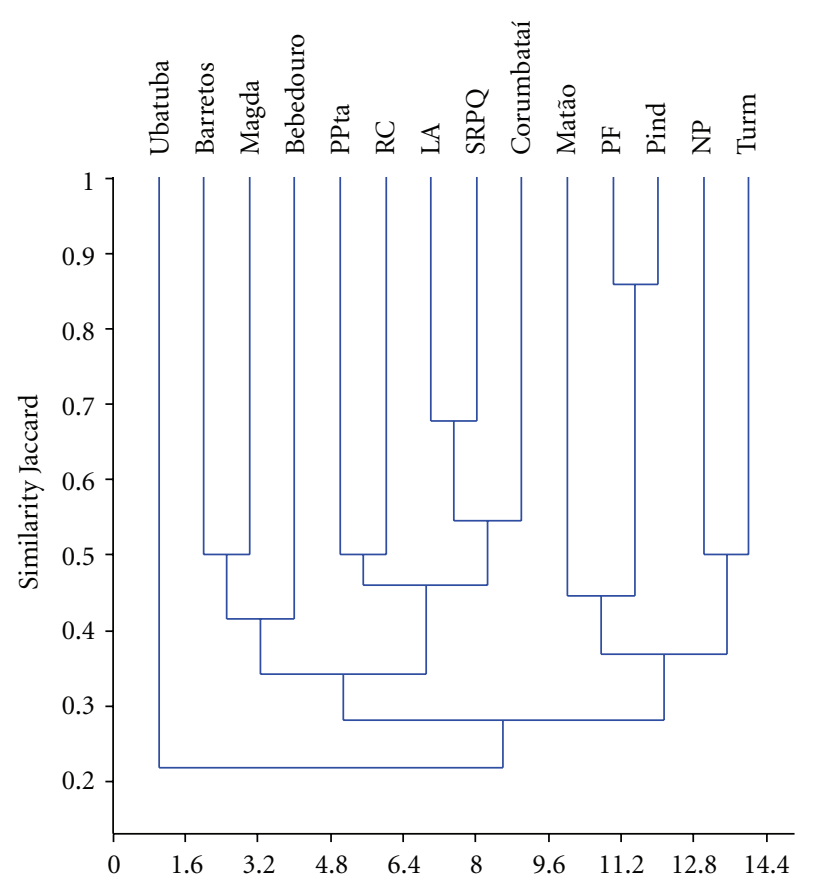

FIGURE 7: Similarity between the areas of São Paulo state where surveys of social wasps were done, using Jaccard index. PPta: Patrocínio Paulista, RC: Rio Claro, LA: Luiz Antônio, SRPQ: Santa Rita do Passa Quatro, PF: Paulo de Faria, Pind: Pindorama, NP: Neves Paulista, Turm: Turmalina.

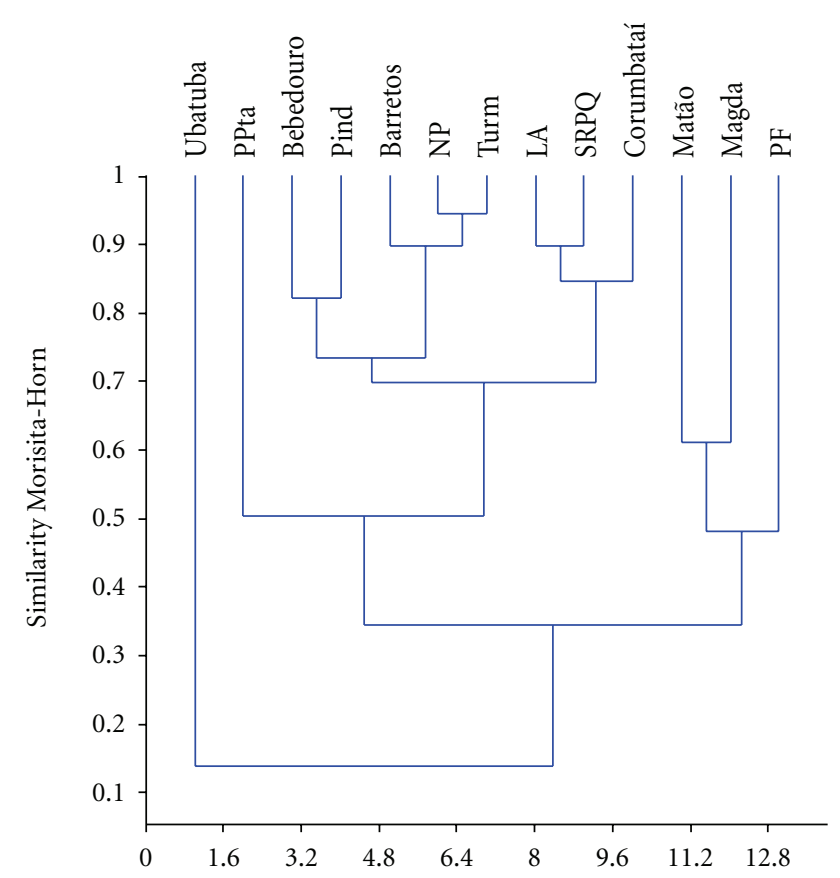

Figure 8: Similarity between the areas of São Paulo state where surveys of social wasps were done, using Morisita-Horn index. PPta: Patrocínio Paulista, Pind: Pindorama, NP: Neves Paulista, Turm: Turmalina, LA: Luiz Antônio, SRPQ: Santa Rita do Passa Quatro, PF: Paulo de Faria.
TABle 2: Diversity, dominance and evenness indexes of the four areas studied.

\begin{tabular}{lcccc}
\hline Indexes & Magda & Bebedouro & Matão & Barretos \\
\hline Diversity Shannon-Wiener & 2.12 & 1.28 & 1.65 & 2.03 \\
Dominance Berger-Parker & 0.23 & 0.61 & 0.45 & 0.45 \\
Evenness Pielou & 0.71 & 0.50 & 0.64 & 0.69 \\
\hline
\end{tabular}

with enormous colonies with great capacity of foraging, and they can establish their colonies in natural cavities [62-64], which may explain their success. Only Mischocyttarus paulistanus was collected exclusively in the fragments surrounded by sugarcane. No species was collected exclusively in the fragments surrounded by citrus.

According to the Shannon-Wiener index, the most diverse area was Magda, followed by Barretos, Matão and Bebedouro (Table 2). Magda had more species and did not show one dominant species. This is confirmed by the low value of Berger-Parker index and high value of Pielou index. The Pielou index also shows high values for Magda, followed by Barretos, Matão and Bebedouro. The higher value of BergerParker index in Bebedouro is because A. pallipes represented $60.57 \%$ of the individuals collected in this area. This species has little habitat specificity in nesting because it builds nests in soil cavities.

Based on the rarefaction curve (Figure 1), it is possible to see that the curves tended to stabilize showing that the collections were sufficient to sample the areas. However, regarding the indexes ACE and ICEs only in Barretos the curve is stabilized showing that all the species of this area were sampled (Figures 2-5).

Comparing our data with those of other authors that had sampled social wasps in São Paulo state [33, 35, 36, 52, 54, $65,66]$ (Figure 6), the Jaccard similarity analysis (Figure 7) demonstrated that Barretos, Magda, and Bebedouro form a cluster, but Matão is more similar to Paulo de Faria and Pindorama. Jaccard coefficient groups localities based on the presence or absence of species.

The similarity analysis of Morisita-Horn (Figure 8), that groups localities based on the relative abundance of species, forms a big cluster with Bebedouro, Pindorama, Barretos, Neves Paulista, Turmalina, Luiz Antônio, Santa Rita do Passa Quatro and Corumbataí. The dominance of A. pallipes in all of these areas explains this group. Matão and Magda form another group with Paulo de Faria mainly because of the similar abundance of A. multipicta and A. vicina.

In comparison with recent surveys of social wasps in São Paulo state, it can be observed that the areas sampled in the present work have less richness than the areas on the centraleastern region of the state (Table 3). Besides the geographic distance and differences on conservation status of the areas and vegetation type, differences in methodologies can explain this fact. The areas on central-western region were sampled with the same methodologies, and, in comparison with these areas, the present study showed a greater richness.

Diniz and Kitayama [38], Silva-Pereira and Santos [46] and Santos et al. [45] noted that some species can set their nests in one environment and forage in others. In this work 
TABle 3: Comparison of the richness of social wasps species of the present work (marked with a*) with recent surveys done in São Paulo state.

\begin{tabular}{lccl}
\hline Surveys & Genera & Species & Methodologies \\
\hline Rodrigues and Machado [33]_Rio Claro & 10 & 33 & Search for colonies \\
Lima et al. [54]_Patrocínio Paulista & 10 & $29^{* *}$ & Attractive solution, collection on flowers and search for colonies \\
Mechi [35]—Luiz Antônio & 9 & 26 & Collection on flowers \\
Mechi [36]—Santa Rita do Passa Quatro & 8 & 26 & Collection on flowers \\
Mechi [35]—Corumbataí & 9 & 25 & Collection on flowers \\
Togni [65]_Ubatuba & 8 & 21 & Bottle-traps, active search \\
Gomes and Noll [52]—Neves Paulista & 7 & 12 & Attractive solution \\
Gomes and Noll [52]_Paulo de Faria & 4 & 7 & Attractive solution, Malaise trap, meat bait, bottle traps \\
Gomes and Noll [52]—Pindorama & 4 & 6 & Attractive solution \\
Lima [66]—Turmalina & 4 & 6 & Attractive solution \\
Magda* & 8 & 20 & Attractive solution \\
Barretos* & 8 & $19^{* *}$ & Attractive solution \\
Bebedouro* & 7 & 13 & Attractive solution \\
Matão* & 6 & 13 & Attractive solution \\
\hline
\end{tabular}

** Two morphs of Polybia fastidiosuscula, but for statistical analysis it was considered only one species.

we noted a greater richness of social wasps in the transect at the edge of the fragments. Lima et al. [54] also found more species at the edge. Santos et al. [43] observed a greater richness of species in environments that were more heterogeneous and that offer more resources than agricultural environments, such as nectar, prey, and water during the year supporting many social wasps [45]. Besides the intense replacement of the natural vegetation in urban areas and agroecosystems, the forest fragments can support social wasps that are important predators of some pests [31, $40]$, benefiting either the natural ecosystem or agrosystems [45].

\section{Conclusions}

We found no correspondence between the occurrence of social wasps and the area of the fragment or the surrounding agricultural matrix. It can be partially explained by the generalist habits of the social wasps. Other factors, such as the interactions between populations and historical aspects, may explain the richness of species on the remnant fragments.

\section{Acknowledgments}

The authors wish to thank Fapesp (07/08633-1) and CNPq for financial support, James M. Carpenter (American Museum of Natural History), Orlando T. Silveira (Museu Paraense Emilio Goeldi), and Sergio R. Andena (Universidade Estadual de Feira de Santana) for identifications of some species. The authors thank John W. Wenzel (Ohio State University) for advice and assistance with the paper.

\section{References}

[1] T. H. Ricketts, "The matrix matters: effective isolation in fragmented landscapes," American Naturalist, vol. 158, no. 1, pp. 87-99, 2001.
[2] J. Vandermeer and C. Carvajal, "Metapopulation dynamics and the quality of the matrix," American Naturalist, vol. 158, no. 3, pp. 211-220, 2001.

[3] P. Kareiva and U. Wennergren, "Connecting landscape patterns to ecosystem and population processes," Nature, vol. 373, no. 6512, pp. 299-302, 1995.

[4] E. S. Jules and P. Shahani, "A broader ecological context to habitat fragmentation: why matrix habitat is more important than we thought," Journal of Vegetation Science, vol. 14, no. 3, pp. 459-464, 2003.

[5] T. Tscharntke and R. Brandl, "Plant-insect interactions in fragmented landscapes," Annual Review of Entomology, vol. 49, pp. 405-430, 2004.

[6] D. M. Debinski and R. D. Holt, "A survey and overview of habitat fragmentation experiments," Conservation Biology, vol. 14, no. 2, pp. 342-355, 2000.

[7] C. A. Kearns, D. W. Inouye, and N. M. Waser, "Endangered mutualisms: the conservation of plant-pollinator interactions," Annual Review of Ecology and Systematics, vol. 29, pp. 83-112, 1998.

[8] G. Durigan, M. F. De Siqueira, and G. A. D. C. Franco, "Threats to the cerrado remnants of the state of São Paulo, Brazil," Scientia Agricola, vol. 64, no. 4, pp. 355-363, 2007.

[9] N. P. Chacoff and M. A. Aizen, "Edge effects on flower-visiting insects in grapefruit plantations bordering premontane subtropical forest," Journal of Applied Ecology, vol. 43, no. 1, pp. 18-27, 2006.

[10] D. Pimentel, U. Stachow, D. A. Takacs et al., "Conserving biological diversity in agricultural/forestry systems," Bioscience, vol. 42, no. 5, pp. 354-362, 1992.

[11] A. C. Melo, G. M. M. Santos, O. M. Marques, and J. D. Cruz, "Vespas Sociais (Vespidae)," in Biodiversidade e Conservação da Chapada Diamantina, F. A. Juncá, L. Funch, and W. Rocha, Eds., pp. 243-257, Ministério do Meio Ambiente, Brasília, Brazil, 2006.

[12] D. Western and M. C. Pearl, Conservation for the Twenty-First Century, Oxford University Press, New York, NY, USA, 1989.

[13] São Paulo (Estado), "Levantamento censitário de unidades de produção agricola do Estado de São Paulo-LUPA 2007/2008," 2008, http://www.cati.sp.gov.br/projetolupa/. 
[14] J. Goldemberg, S. T. Coelho, and P. Guardabassi, "The sustainability of ethanol production from sugarcane," Energy Policy, vol. 36, no. 6, pp. 2086-2097, 2008.

[15] R. A. Araújo, M. S. Araújo, A. H. R. Gonring, and R. N. C. Guedes, "Impacto da queima controlada da palhada da canade-açúcar sobre a comunidade de insetos locais," Neotropical Entomology, vol. 34, no. 4, pp. 649-658, 2005.

[16] T. Szmrecsányi, "Tecnologia e degradação ambiental: O caso da agroindustria canavieira no estado de Sao Paulo," Informações Econômicas, vol. 24, pp. 73-82, 1994.

[17] J. R. Miranda and E. E. Miranda, "Biodiversidade e sistemas de produção orgânicos: recomendações no caso da cana-deaçúcar," Embrapa Monitoramento por Satélite, Documentos, vol. 27, pp. 1-94, 2004.

[18] IBGE, "Tabela 1613-Quantidade produzida, Valor da produção, Área plantada e Área colhida da lavoura permanente," 2009, http://www.sidra.ibge.gov.br/bda/tabela/listabl .asp? $\mathrm{c}=1613 \& \mathrm{z}=\mathrm{t} \& \mathrm{o}=11$.

[19] C. Westphal, I. Steffan-Dewenter, and T. Tscharntke, "Mass flowering crops enhance pollinator densities at a landscape scale," Ecology Letters, vol. 6, no. 11, pp. 961-965, 2003.

[20] I. M. P. Rinaldi, B. P. Mendes, and A. B. Cady, "Distribution and importance of spiders inhabiting a Brazilian sugar cane plantation," Revista Brasileira de Zoologia, vol. 19, no. 1, pp. 271-279, 2002.

[21] A. P. Ott, R. Ott, and V. R. S. Wolff, "Araneofauna de pomares de laranja Valência nos Vales do Caí e Taquari, Rio Grande do Sul, Brasil," Iheringia Serie Zoologia, vol. 97, no. 3, pp. 321327, 2007.

[22] S. R. Andena, L. R. Bego, and M. R. Mechi, "A Comunidade de abelhas (Hymenoptera, Apoidea) de uma area de cerrado (Corumbataí, SP) e suas visitas às flores," Revista Brasileira de Zoociências, vol. 7, no. 1, pp. 55-91, 2005.

[23] M. J. O. Campos, Estudo das interaçães entre comunidade de Apoidea, na procura de recursos alimentares, e a vegetação de cerrado da Reserva de Corumbataí-SP, Ph.D. thesis, Universidade Federal de São Carlos, São Carlos, Brazil, 1989.

[24] D. T. Malerbo-Souza, R. H. Nogueira-Couto, and L. A. Couto, "Polinização em cultura de laranja (Citrus sinensis L. Osbeck, var. Pera-rio)," Brazilian Journal of Veterinary Research and Animal Science, vol. 40, pp. 237-242, 2003.

[25] L. M. Gamito and D. T. Malerbo-Souza, "Visitantes florais e produção de frutos em cultura de laranja (Citrus sinensis L. Osbeck)," Acta Scientiarum: Animal Sciences, vol. 28, no. 4, pp. 483-488, 2006.

[26] R. M. De Morais, A. Barcellos, and L. R. Redaelli, "Insetos predadores em copas de Citrus deliciosa (Rutaceae) sob manejo orgânico no sul do Brasil," Iheringia Serie Zoologia, vol. 96, no. 4, pp. 419-424, 2006.

[27] R. Gadagkar, "Belanogaster, Myschocyttarus, Parapolybia, and independent-founding Ropalidia," in The Social Biology of Wasps, K. G. Ross and R. W. Mathews, Eds., pp. 149-190, Cornell University Press, New York, NY, USA, 1991.

[28] R. L. Rabb, "Biological studies of Polistes in North Carolina (Hymenoptera: Vespidae)," Annals of the Entomological Society of America, vol. 53, pp. 111-121, 1960.

[29] M. Raveret Richter, "Social wasp (Hymenoptera: Vespidae) foraging behavior," Annual Review of Entomology, vol. 45, pp. 121-150, 2000.

[30] R. L. Jeanne and B. J. Taylor, "Individual and social foraging in social wasps," in Food Exploitation by Social Insects: Ecological, Behavioral and Theoretical approaches, S. Jarau and M. Hrncir, Eds., pp. 53-79, CRC Press, Boca Raton, Fla, USA, 2009.
[31] F. Prezoto, H. H. Santos-Prezoto, V. L. L. Machado, and J. C. Zanuncio, "Prey captured and used in Polistes versicolor (Olivier) (Hymenoptera: Vespidae) nourishment," Neotropical Entomology, vol. 35, no. 5, pp. 707-709, 2006.

[32] O. W. Richards, The Social Wasps of the Americas Excluding the Vespinae, British Museum (Natural History), London, UK, 1978.

[33] V. M. Rodrigues and V. L. L. Machado, "Vespídeos Sociais: Espécies do Horto Florestal "Navarro de Andrade" de Rio Claro, SP,” Naturalia, vol. 7, pp. 173-175, 1982.

[34] B. B. Santos, "Ocorrência de vespídeos sociais (Hymenoptera, Vespidae) em pomar em Goiânia, Goiás, Brasil,” Agrárias, vol. 15, no. 1, pp. 43-46, 1996.

[35] M. R. Mechi, Levantamento da fauna de vespas Aculeata na vegetação de duas áreas de cerrado, Ph.D. thesis, Universidade Federal de São Carlos, São Carlos, Brazil, 1996.

[36] M. R. Mechi, "Comunidade de vespas Aculeata (Hymenoptera) e suas fontes florais," in O Cerrado Pé-de-Gigante: Ecologia e Conservação-Parque Estadual de Vassununga, V. R. Pivello and E. M. Varanda, Eds., pp. 256-265, Secretaria do Meio Ambiente, São Paulo, Brazil, 2005.

[37] I. R. Diniz and K. Kitayama, "Colony densities and preferences for nest habitats of some social wasps in Mato Grosso State, Brazil (Hymenoptera: Vespidae)," Journal of Hymenoptera Research, vol. 3, pp. 133-143, 1994.

[38] I. R. Diniz and K. Kitayama, "Seasonality of vespid species (Hymenoptera: Vespidae) in a central Brazilian cerrado," Revista de Biología Tropical, vol. 46, no. 1, pp. 109-114, 1998.

[39] O. T. Silveira, "Surveying neotropical social wasps. An evaluation of methods in the "ferreira penna8221; research station (ECFPn), in caxiuanã, PA, brazil (HYM., vespidae, polistinae)," Papéis Avulsos de Zoologia, vol. 42, no. 12, pp. 299-323, 2002.

[40] O. M. Marques, P. A. Santos, A. F. Vinhas, A. L. V. Souza, C. A. L. Carvalho, and J. L. Meira, "Vespas Sociais (Hymenoptera: Vespidae) visitantes de nectários de Vigna unguiculata (L.) Walp. na região do Recôncavo da Bahia," Magistra, vol. 17, pp. 64-68, 2005.

[41] M. G. Hermes and A. Köhler, "The flower-visiting social wasps (Hymenoptera, Vespidae, Polistinae) in two areas of Rio Grande do Sul State, southern Brazil," Revista Brasileira de Entomologia, vol. 50, no. 2, pp. 268-274, 2006.

[42] G. M. M. Santos, C. M. L. Aguiar, and N. Gobbi, "Characterization of the social wasp guild (Hymenoptera: Vespidae) visiting flowers in the Caatinga (Itatim, Bahia, Brazil)," Sociobiology, vol. 47, no. 2, pp. 483-494, 2006.

[43] G. M. M. Santos, C. C. Bichara Filho, J. J. Resende, J. D. Da Cruz, and O. M. Marques, "Diversity and community structure of social wasps (Hymenoptera: Vespidae) in three ecosystems in Itaparica Island, Bahia State, Brazil," Neotropical Entomology, vol. 36, no. 2, pp. 180-185, 2007.

[44] G. M. M. Santos, P. C. Bispo, and C. M. L. Aguiar, "Fluctuations in richness and abundance of social wasps during the dry and wet seasons in three phyto-physiognomies at the tropical dry forest of Brazil," Environmental Entomology, vol. 38, no. 6, pp. 1613-1617, 2009.

[45] G. M. M. Santos, J. D. da Cruz, O. M. Marques, and N. Gobbi, "Diversidade de vespas sociais (Hymenoptera: Vespidae) em Áreas de Cerrado na Bahia," Neotropical Entomology, vol. 38, no. 3, pp. 317-320, 2009.

[46] V. D. A. Silva-Pereira and G. M. M. Santos, "Diversity in bee (Hymenoptera: Apoidea) and social wasp (Hymenoptera: Vespidae, Polistinae) community in "Campos Rupestres", 
Bahia, Brazil," Neotropical Entomology, vol. 35, no. 2, pp. 165174, 2006.

[47] M. M. De Souza and F. Prezoto, "Diversity of social wasps (Hymenoptera: Vespidae) in semideciduous forest and cerrado (savanna) regions in Brazil," Sociobiology, vol. 47, no. 1, pp. 135-147, 2006.

[48] C. M. L. Aguiar and G. M. M. Santos, "Compartilhamento de recursos florais por vespas sociais (Hymenoptera: Vespidae) e abelhas (Hymenoptera: Apoidea) em uma área de caatinga," Neotropical Entomology, vol. 36, no. 6, pp. 836-842, 2007.

[49] A. Elpino-Campos, K. Del-Claro, and F. Prezoto, "Diversity of social wasps (Hymenoptera: Vespidae) in Cerrado fragments of Uberlândia, Minas Gerais State, Brazil," Neotropical Entomology, vol. 36, no. 5, pp. 685-692, 2007.

[50] E. F. Morato, S. T. Amarante, and O. T. Silveira, "Avaliação ecológica rápida da fauna de vespas (Hymenoptera: Aculeata) do Parque Nacional da Serra do Divisor, Acre, Brasil," Acta Amazonica, vol. 38, no. 4, pp. 789-797, 2008.

[51] O. T. Silveira, S. V. Da Costa Neto, and O. F. M. Da Silveira, "Social wasps of two wetland ecosystems in brazilian Amazonia (Hymenoptera, Vespidae, Polistinae)," Acta Amazonica, vol. 38, no. 2, pp. 333-344, 2008.

[52] B. Gomes and F. B. Noll, "Diversity of social wasps (Hymenoptera, Vespidae, Polistinae) in three fragments of semideciduous seasonal forest in the northwest of São Paulo State, Brazil," Revista Brasileira de Entomologia, vol. 53, no. 3, pp. 428-431, 2009.

[53] S. S. Silva and O. T. Silveira, "Vespas sociais (Hymenoptera, Vespidae, Polistinae) de floresta pluvial Amazônica de terra firme em Caxiuanã, Melgaço, Pará,” Iheringia Serie Zoologia, vol. 99, no. 3, pp. 317-323, 2009.

[54] A. C. O. Lima, M. S. M. Castilho-Noll, B. Gomes, and F. B. Noll, "Social wasp diversity (Vespidae, Polistinae) in a forest fragment in the northeast of são paulo state sampled with different methodologies," Sociobiology, vol. 55, no. 2, pp. 613626, 2010.

[55] G. M. M. Santos and S. J. Presley, "Niche overlap and temporal activity patterns of social wasps (Hymenoptera: Vespidae) in a Brazilian Cashew Orchard," Sociobiology, vol. 56, no. 1, pp. 121-131, 2010.

[56] F. J. N. Kronka, C. K. Matsukuma, M. A. Nalon et al., Inventário florestal do Estado de São Paulo, Instituto Florestal, São Paulo, Brazil, 1993.

[57] F. B. Noll and B. Gomes, "An improved bait method for collecting Hymenoptera, especially social wasps (Vespidae: Polistinae)," Neotropical Entomology, vol. 38, no. 4, pp. 477481, 2009.

[58] O. Hammer, D. A. T. Harper, and P. D. Ryan, "Past: Paleontological Statistics Software Package for Education and Data Analysis, Version 1.37," Palaeontologica Electronica 4, 1-9, 2005.

[59] R. K. Colwell, EstimateS: Statistical Estimation of Species Richness and Shared Species from Samples. Version 7.0, User's guide and application, 2004.

[60] N. McAleece, P. J. D. Lambshead, G. L. J. Paterson, and J. D. Gage, BioDiversity Professional Beta, The Natural History Museum \& The Scottish Association for Marine Science, 1997.

[61] A. R. Ometto, E. E. Miranda, and J. A. C. Mangabeira, "Perfil tecnológico e socioeconômico das principais atividades agrossilvipastoris do nordeste paulista," Embrapa Monitoramento por Satélite, Documentos, vol. 40, pp. 1-61, 2005.

[62] R. Zucchi, S. F. Sakagami, F. B. Noll et al., "Agelaia vicina, a swarm-founding polistine with the largest colony size among wasps and bees (Hymenoptera: Vespidae)," Journal of New York Entomological Society, vol. 103, no. 2, pp. 129-137, 1995.

[63] F. B. Noll, D. Simöes, and R. Zucchi, "Morphological caste differences in the neotropical swarm-founding polistinae wasps: Agelaia m. multipicta and A. p. pallipes (Hymenoptera vespidae)," Ethology Ecology and Evolution, vol. 9, no. 4, pp. 361-372, 1997.

[64] O. A. L. Oliveira, F. B. Noll, and J. W. Wenzel, "Foraging behavior and colony cycle of Agelaia vicina (Hymenoptera: Vespidae; Epiponini)," Journal of Hymenoptera Research, vol. 19, no. 1, pp. 4-11, 2010.

[65] O. C. Togni, Diversidade de vespas sociais (Hymenoptera, Vespidae) na Mata Atântica do litoral norte do estado de São Paulo, M.S. thesis, Universidade Estadual Paulista, Rio Claro, Brazil, 2009.

[66] A. C. O. Lima, Sobre a diversidade das vespas sociais (Vespidae: Polistinae) em fragmentos florestais remanescentes do noroeste $e$ do nordeste do estado de São Paulo, e o seu possível uso como indicadores de conservação da biodiversidade, M.S. thesis, Universidade de São Paulo, Ribeirão Preto, Brazil, 2008. 

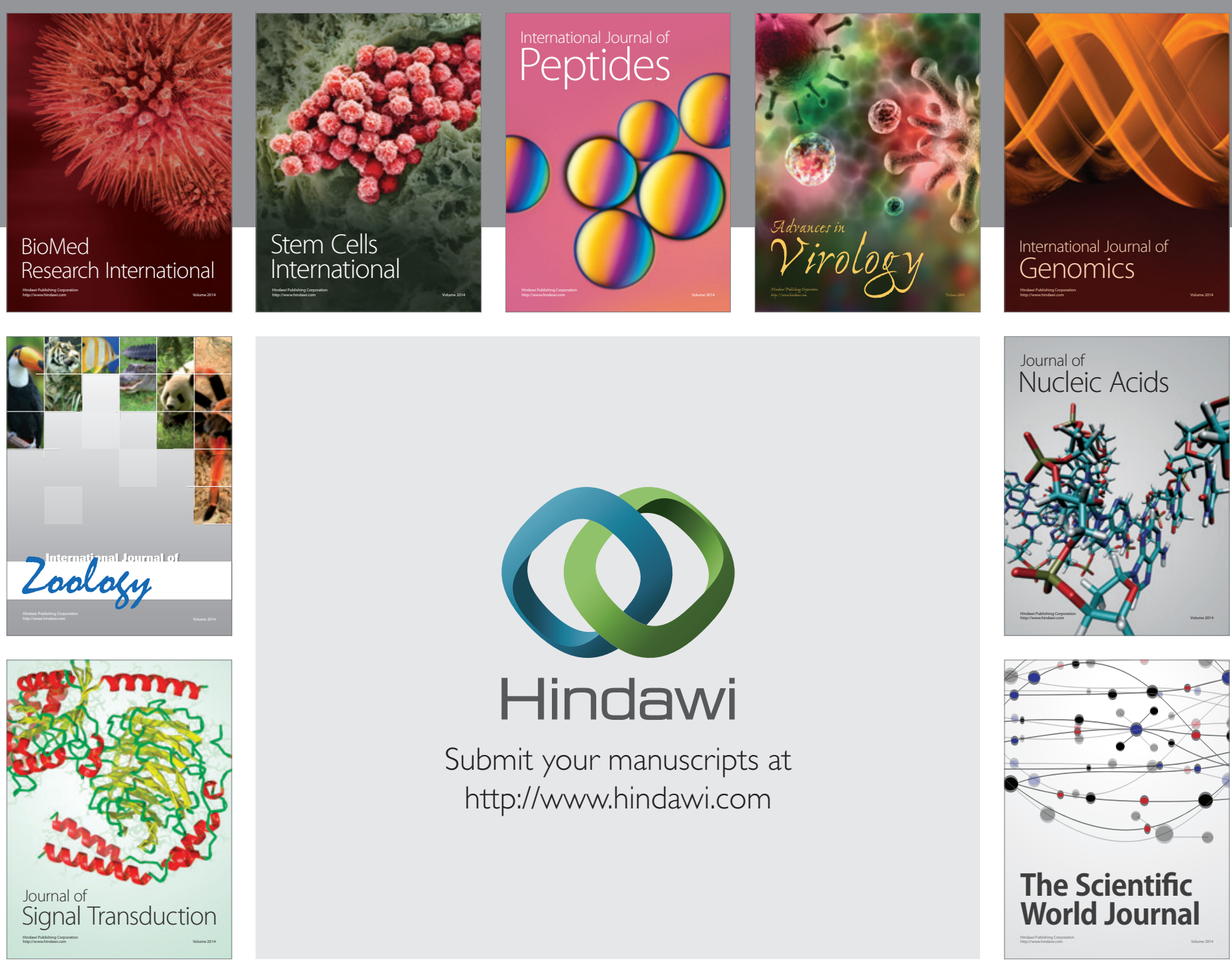

Submit your manuscripts at

http://www.hindawi.com
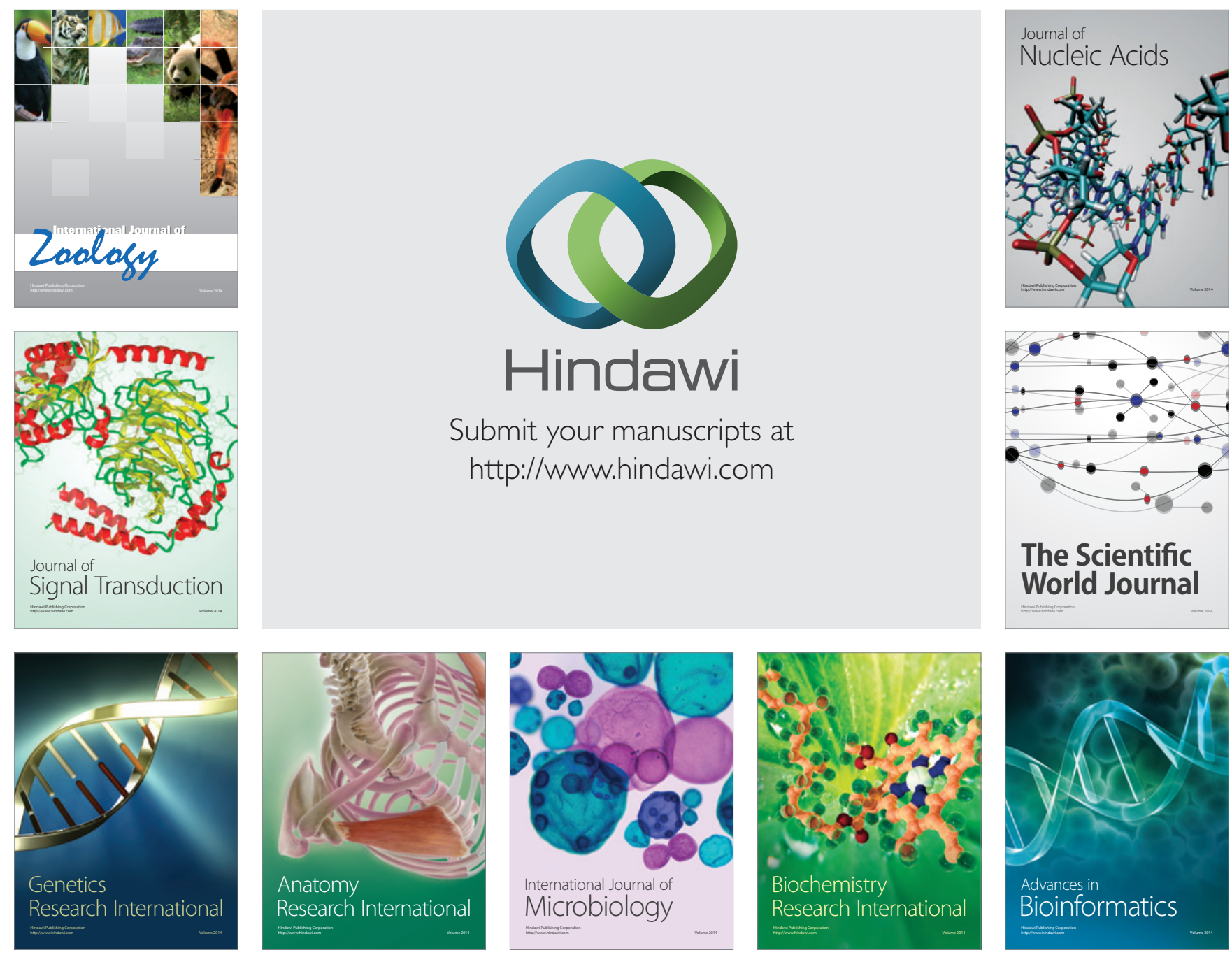

The Scientific World Journal
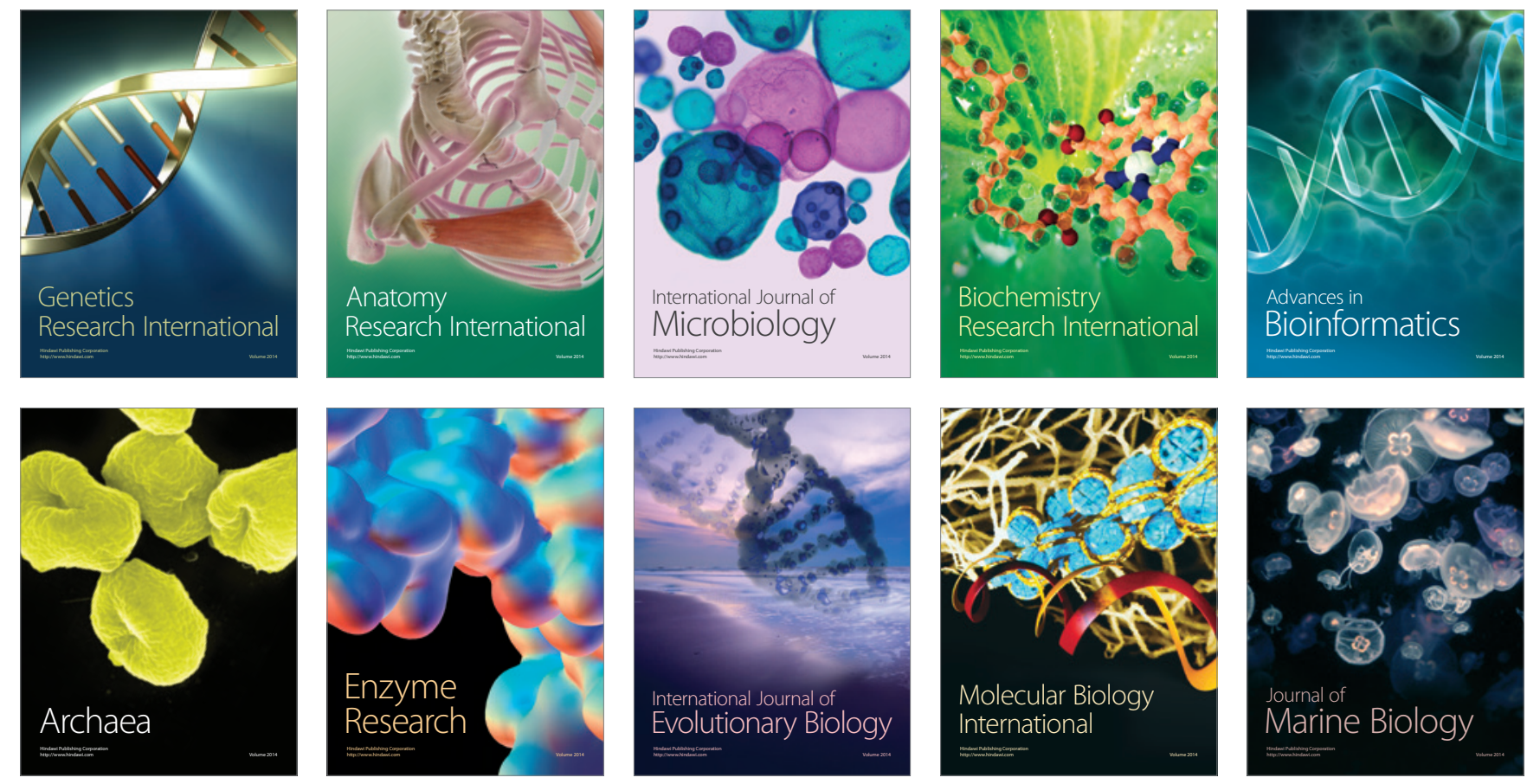